\title{
From 25 Years Ago \\ Range Technology Must Be Extended
}

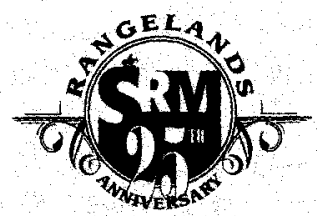

\section{Through the Extension Service's model of 'Helping People Help Themselves" adoption of new technology can be increased.}

\author{
By Bob J. Ragsdale
}

As a tribute to the $25^{\text {th }}$ anniversary of "Rangelands," we are including comments and articles from past SRM events and issues of the publication. These brief glimpses back in time offer a reminder of where we've been and how far we've come. The following article was adapted for publication from a presentation the author made at the First International Rangeland Congress in Denver, Colorado in August 1978.

"What a man hears, he may doubt; what he sees, he may also doubt; but what he does, he cannot doubt. .." This is the philosophy of Dr. Seaman A. Knapp, who pioneered an informal education method of teaching farmers and ranchers. This paper considers the application of Dr. Knapp's philosophy to current range technology.

Much research has been conducted in the field of range and rangeland problems. A continuing and expanding interest in rangeland around the world dictates that research will remain in existence and, hopefully, be increased. New scientific information and technology has been developed and more will be forthcoming. How will this new information and technology be used? It could be placed in file cabinets, hidden away in research publications, or it could collect dust in libraries. Range users and managers must use it; but first, there must be an operative vehicle to get it into their hands.

There is a method of informal education which can get new technology into the hands of the private land owners and get it adopted by them. It is a program which is conducted by a state Extension Service cooperatively with the United States Department of Agriculture, a land grant university, and the lay people who apply the information to their local needs. The mechanics of the program discussed hereafter will be of the Texas Agricultural
Extension Service. Program results from Sutton County, Texas, will be used to illustrate the adoption and practical application of new information and technology.

\section{A Texas Case Study}

First, let us take a brief look at the organization of the Texas Agricultural Extension Service. The Texas Agricultural Extension Service is a part of Texas A\&M University System, the land grant university in Texas, and of the Science and Education Administration of the United States Department of Agriculture. County Extension workers are located in most of the 254 counties in Texas. Eight specialists are responsible for range science: three serve the entire state while five have responsibilities for specific geographic areas.

The basic individual is the county Extension representative who works with the people in delineating problems, developing educational programs, and implementing these programs to solve local problems. The specialist staff, available at area and state levels to support and service the county programs, may also determine problem areas and convey the need for more intensive studies to the researchers of the Texas Agricultural Experiment Station. In addition to the county workers and area or state specialists, supervisory, service, and administrative units are also present. Extension education is a part of all levels of government-county, state and federal-and receives funding from all three.

Extension programs developed for all citizens adult and youth - are directed primarily to agriculture and home economics, but include related areas. These educational programs are based on the prob- 
lems as perceived by the laymen. They are longrange in nature, but specific goals are established and worked on each year. These lay people are selected and organized into groups to study major agricultural commodity needs as well as other problem areas dictated by the county situation. Range programs may be handled by a Range Committee, but also they may come under natural resources, forage, livestock, or wildlife committees. Smaller over-all committees exist to coordinate the activities of the commodity and special interest areas. Together, these committees form the county program building effort at the "grass roots" level.

Many teaching methods are included in Extension educational programs. Some of these are:

a) Media releases through newspapers, radio, and television to reach large audiences;

b) Individual contacts by telephone, letter, and personal conversations to reach key individuals

c) Tours and field days to observe research and demonstration results, as well as show techniques and practices;

d) Publications to provide written subject matter information; and

e) Demonstrations, result and method, to teach new technology and methods. The demonstration is the basic and key Extension method of teaching.

The effectiveness of a sound Extension program was illustrated in Sutton County in Southwest Texas, which is primarily rangeland. The area, like much of Texas, has experienced a steady increase of certain noxious plants, both woody and herbaceous, over the past 75 years. It is a county where the range forage supports cattle, sheep, goats and white-tailed deer on the same land. Extension programs have been utilized for many years with strong emphasis on range management, livestock production, deer management, and wool and mohair improvement. A unit of the Texas Agricultural Experiment Station which conducts range research is located in the county.

Key members of the Range Committee of Sutton County are ranchers, most of whom serve as directors of the local soil and water conservation district, the Soil Conservation Service personnel, and the director of the Texas Agricultural Experiment Station unit. Some of the rancher-members also serve as demonstration cooperators.
With the advent of the herbicide $2,4,5-\mathrm{T}$ in the late 1940's, the development of a recommendation for its use to control brush, primarily mesquite (Prosopis glandulosa Torr.), and the resulting education programs, this method of controlling brush was adopted and used by ranchers in Sutton County. When the herbicide mixture picloram and 2,4,5- T became available, and research indicated it was more effective than 2,4,5- $\mathrm{T}$ alone, the Sutton County Range Committee wanted the ranchers to change to this material to speed up range improvement, the overriding goal of woody plant control. Specialist assistance was requested by the Committee to provide guidance in planning and conducting result demonstrations to show the effectiveness of the new herbicide mixture of picloram and 2,4,5- $\mathrm{T}$.

Demonstrations planned and conducted involved certain respected, innovative, and progressive ranchers who were willing to try the new herbicide mixture. Applications using 2,4,5- T alone compared to the herbicide mixture were made at a number of strategic 1ocations in the county. Extension Range Specialists and Soil Conservation Service personnel were utilized to assist in the evaluation of the demonstrations.

The results were disseminated to other ranchers through a County Demonstration Handbook and at publicly conducted field days. The end result of this Extension-sponsored demonstration was a near $100 \%$ shift to the new material, and an increase in livestock production from the treated acreage, and no harmful effects to wildlife or wildlife habitat, which further illustrates the benefits of extending new technology.

\section{Another Example}

Bitterweed (Hymenoxys odorata DC), an herbaceous plant, causes death losses in sheep most years; losses may run as high as $15-20 \%$ of the flock. Research has shown that deferred- rotation grazing, as well as combination stocking, can reduce death losses. Research has also shown that 2,4-D is effective in controlling bitterweed under certain conditions. Latest research investigations indicate that a cool-season application of this herbicide shows promise for controlling the plant.

The Range Committee followed the previously mentioned procedure and, with specialist assistance, 
designed a demonstration to show the value of controlling bitterweed using 2,4-D with a deferred grazing program. The rancher-cooperator deferred a pasture during the warm growing season and treated it with $2,4-\mathrm{D}$ in early winter. When evidence of bitterweed toxicity was noticed, sheep were concentrated in the demonstration pasture. Bitterweed was not completely controlled, but the amount consumed by each sheep was drastically reduced. As more desirable forage was available, less supplemental feed was required; less labor was needed to handle the flock; and the pasture furnished forage in late winter-early spring for replacement heifers. Death losses were greatly reduced-the major goal of the demonstration. An economic analysis indicated it was a favorable program.

Results were again disseminated in the Demonstration Handbook, toxicology seminars, sheep production short courses, and by newspaper releases. More importantly, a number of other ranchers adopted similar programs.

In summary, a comprehensive and progressive Extension education program can result in new technology and scientific information being put into practical and successful use by farmers and ranchers-the direct benefactors of such advances in research. Through this approach, the philosophy of the Texas Agricultural Extension Service of "Helping People Help Themselves" is put into practice.

\footnotetext{
About the Author: Bob Ragsdale is a Project Leader in range science and Range Specialist Texas Agricultural Extension Service, College Station, Texas 77843.
}

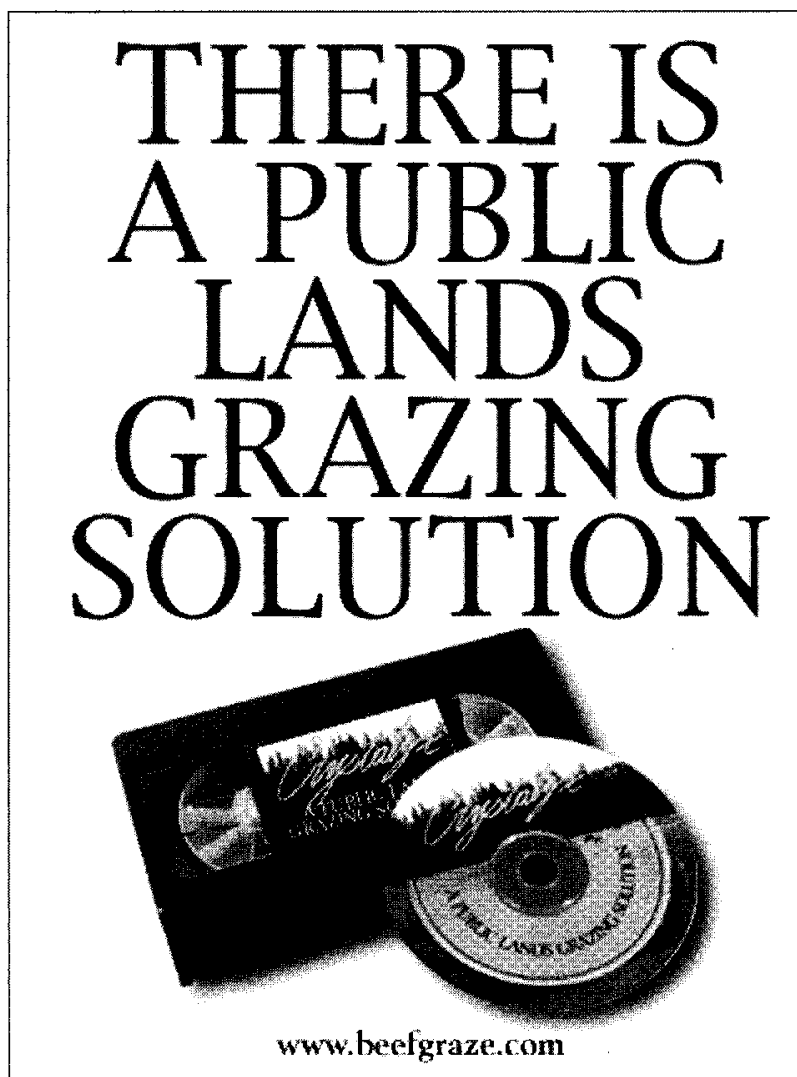

Find out how it can work for you.

This FREE video will describe to you recent research about a proven solution for grazing public lands using CRYSTALYX ${ }^{\circledR}$ Brand Supplements.

Applied appropriately, you can maintain and possibly increase your AUM's harvested.

To order your FREE video, DVD or CD-ROM and a six-page Public Lands article, call 1-866-635-3718 or go to www.beefgraze.com.

Take the first step by submitting your request to: www.beefgraze.com or call 1-866-635-3718

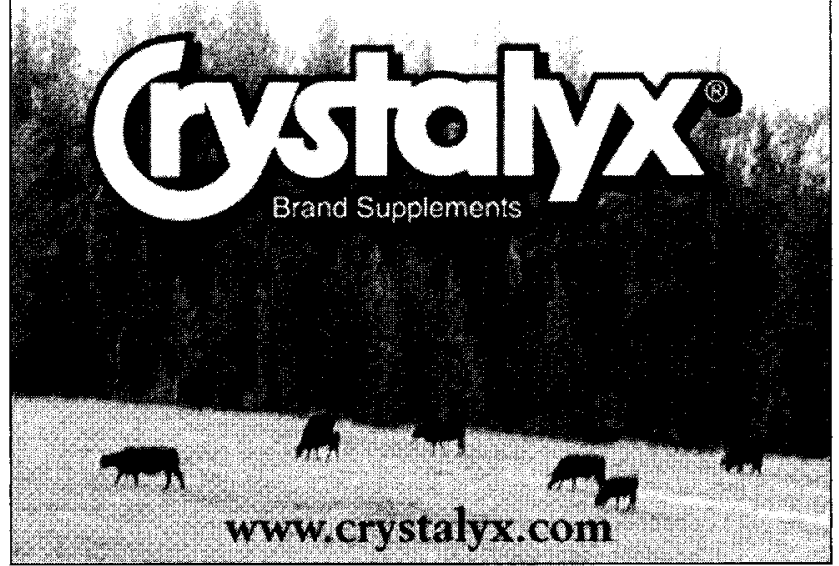

